IZA DP No. 4185

A Reevaluation of the Role of Family in Immigrants' Labor Market Activity: Evidence from a Comparison of Single and Married Immigrants

Sarit Cohen-Goldner

Chemi Gotlibovski

Nava Kahana

May 2009 


\title{
A Reevaluation of the Role of Family in Immigrants' Labor Market Activity: Evidence from a Comparison of Single and Married Immigrants
}

\author{
Sarit Cohen-Goldner \\ Bar Ilan University and IZA \\ Chemi Gotlibovski \\ Academic College of Tel-Aviv Yaffo \\ Nava Kahana \\ Bar Ilan University and IZA
}

Discussion Paper No. 4185

May 2009

IZA

P.O. Box 7240

53072 Bonn

Germany

Phone: +49-228-3894-0

Fax: +49-228-3894-180

E-mail: iza@iza.org

\begin{abstract}
Any opinions expressed here are those of the author(s) and not those of IZA. Research published in this series may include views on policy, but the institute itself takes no institutional policy positions.

The Institute for the Study of Labor (IZA) in Bonn is a local and virtual international research center and a place of communication between science, politics and business. IZA is an independent nonprofit organization supported by Deutsche Post Foundation. The center is associated with the University of Bonn and offers a stimulating research environment through its international network, workshops and conferences, data service, project support, research visits and doctoral program. IZA engages in (i) original and internationally competitive research in all fields of labor economics, (ii) development of policy concepts, and (iii) dissemination of research results and concepts to the interested public.
\end{abstract}

IZA Discussion Papers often represent preliminary work and are circulated to encourage discussion. Citation of such a paper should account for its provisional character. A revised version may be available directly from the author. 


\begin{abstract}
A Reevaluation of the Role of Family in Immigrants' Labor Market Activity: Evidence from a Comparison of Single and Married Immigrants*

Previous papers tested the validity of the Family Investment Hypothesis (FIH) among immigrants by comparing the labor market outcomes of immigrant couples and native or mixed couples. Here we propose an alternative test for the FIH which is based on a comparison between married and single immigrants. The logic underlying this alternative method states that if credit constraints are binding, then only married immigrants can crossfinance their investment within the family. In order to overcome potential selection bias that would arise if unobserved characteristics that affect the marital status of the individual also affect his/her labor market outcomes, we construct a difference-in-differences estimator that exploits variation in the labor market outcomes of married and single natives. Implementation of this method using US and Israeli data leads to a rejection of the FIH in both countries.
\end{abstract}

JEL Classification: J22, J61

Keywords: family investment model, labor supply

Corresponding author:

Sarit Cohen-Goldner

Department of Economics

Bar-Ilan University

52900 Ramat-Gan

Israel

E-mail: cohens1@mail.biu.ac.il

Cohen-Goldner and Kahana acknowledge generous support from the Adar foundation. CohenGoldner also acknowledges generous support from GIF (German Israeli Foundation). Gotlibovski acknowledges generous support of the Academic College of Tel-Aviv Yaffo. 


\section{Introduction}

According to the Family Investment Hypothesis (FIH), credit-constrained immigrant families adopt a household strategy upon arrival in order to finance the acquisition of human capital. According to this strategy, one spouse invests in host-country-specific human capital while the other enters the labor market in order to finance their current consumption. Any evidence that the secondary worker in the family works longer hours and foregoes investment in human capital by initially taking better-paying but "dead-end” jobs in comparison to her/his native counterpart, is taken as support for the hypothesis and for the existence of binding liquidity constraints.

Several papers have attempted to examine the FIH in the US. ${ }^{1}$ Duleep and Sanders (1993) and McPherson and Stewart (1989) used a single cross-section and found their results to be consistent with the FIH. Duleep and Dowhan (2002) used longitudinal data while Blau et al. (2003) used repeated cross-sections and both concluded that in contrast to the family investment model, both spouses in an immigrant family invest primarily in their own human capital rather than their spouse's. These papers tested the validity of the FIH based on a comparison between native and immigrant couples. ${ }^{2}$ However, this type of comparison may be problematic since the behavior of immigrants may differ from that of natives for reasons other than binding liquidity constraints, such as differences in work habits, culture and the self-selection of immigrants.

This paper offers an alternative methodology and interpretation to the conventional method for testing the FIH which is based on a more appealing comparison between married and single immigrants. The motivation for this approach stems from the fact that if indeed immigrants face binding liquidity constraints, then a single immigrant may not have enough resources to finance his investment in local human capital, while a married immigrant has access to family resources (i.e. his spouse's income). However, if individuals are self-selected into marriage with respect to unobserved characteristics and these unobservables affect labor outcomes, then the direct comparison between married and single immigrants may lead to a specious conclusion regarding the validity of the FIH. To control for this potential selection bias, we exploit the variation in the labor supply and wages of married and single natives, who are not expected to face binding

\footnotetext{
1 There is an extensive literature that attempts to empirically test the FIH in other countries as well. For example, Beach and Worswick (1993), Worswick (1996, 1999) and Baker and Benjamin (1997) in Canada and Cobb-Clark and Crossley (2004) in Australia.

${ }^{2}$ Some papers also included mixed couples, i.e. couples with one immigrant spouse and one native spouse, in their samples.
} 
liquidity constraints, in order to construct a difference-in-differences (hereafter: Dif-in-Dif) estimator for the evaluation of the FIH.

Formally, denote by $Y_{I M}^{m}$ and $Y_{I M}^{s}$ the outcomes (i.e. labor supply or wage) for a married male immigrant and a single male immigrant, respectively, and by $Y_{N}^{m}$ and $Y_{N}^{s}$ the outcomes of a married male native and a single male native, respectively. Our Dif-in-Dif estimator is therefore defined as: $\left(Y_{I M}^{m}-Y_{I M}^{s}\right)-\left(Y_{N}^{m}-Y_{N}^{s}\right)$ which is equivalent to $\left(Y_{I M}^{m}-Y_{N}^{m}\right)-\left(Y_{I M}^{s}-Y_{N}^{s}\right)$. The estimator used in previous papers was $\left(Y_{I M}^{m}-Y_{N}^{m}\right)$ (hereafter referred to as the conventional estimator). Thus, the conventional estimator can be viewed as a special case of our proposed estimator where $\left(Y_{I M}^{s}-Y_{N}^{s}\right)=0 .^{3}$

We use the new estimator to test the FIH in the US and Israel. For Israel, we focused only on immigrants from the Former Soviet Union (FSU). ${ }^{4}$ Most of these immigrants have a college education and had worked in their source country in highly-skilled occupations. Their transition from a communist regime to a developed economy required an adjustment of their imported skills to the requirements of the Israeli labor market. Thus, the use of the Israeli data is an attempt to test the FIH among highly-skilled immigrants who are more likely to invest in human capital appropriate to the new country.

Using the 1980 and 1990 US censuses, we found that $\left(Y_{I M}^{s}-Y_{N}^{s}\right) \neq 0$ for both males and females. Specifically, after about five years in the US, single immigrants (both male and female) earn more than comparable single natives. Regarding labor supply, a single male immigrant initially works less than a comparable native but after about eight years he is working more, while a single female immigrant always works less than her native counterpart. We found that $\left(Y_{I M}^{s}-Y_{N}^{s}\right) \neq 0$ for both males and females in Israel as well, such that single male and female natives initially earn more than comparable single immigrants but that this pattern is reversed after about 18 years for males and 23 years for females. The labor supply pattern for single immigrants in Israel is quite similar to that for single male immigrants in the US, such that upon arrival in Israel single immigrants (both male and female) work less than their native counterparts but after about eight years in the country the situation is reversed.

Which predictions of the Dif-in-Dif approach would be consistent with the FIH? Under the assumption that the primary worker is the husband, we would expect that if we control for the

\footnotetext{
${ }^{3}$ Identical estimators are constructed for females.

${ }^{4}$ In the US we do not restrict ourselves to specific source countries.
} 
hours/wage gap between married and single native males, then an immigrant husband would initially work (and earn) less but will experience a higher growth rate in hours and wage than a single male immigrant. In addition, if we control for the hours/wage gap between married and single female natives, then an immigrant wife would initially work (and earn) more than a single female immigrant, but her wage growth will be lower. ${ }^{5}$ Alternatively, recalling that our estimator can also be written as $\left(Y_{I M}^{m}-Y_{N}^{m}\right)-\left(Y_{I M}^{s}-Y_{N}^{s}\right)$, we would expect that the difference in the growth in work hours and wages between immigrant and native husbands will be higher than that between single male immigrants and single male natives, while the difference in growth in work hours and wages between immigrant and native wives will be lower than that between single female immigrants and single female natives.

To illustrate the difference between the conventional estimator and Dif-in-Dif, note that in the conventional evaluation of the FIH the observation that the primary worker (male) in the family initially works fewer hours but eventually overtakes his native counterpart is viewed as support for the FIH. However, in our strategy the same pattern can be viewed as contradicting the hypothesis if the gap in hours between single male immigrants and single male natives (i.e. $Y_{I M}^{s}-Y_{N}^{s}$ ) grows at a faster rate than that between married male immigrants and married male natives $\left(Y_{I M}^{m}-Y_{N}^{m}\right)$.

Using the Dif-in-Dif approach, which controls for the difference between married and single natives, we find that among immigrants to the US, both male and female married immigrants initially earn less than their single immigrant counterparts, but that after about 9-10 years they in fact earn more. These positive wage assimilation profiles for married immigrants (relative to single immigrants) contradict the FIH and suggest that neither married female immigrants nor married male immigrants take "dead-end" jobs in the US.

With regard to labor supply, we find that both single and married male immigrants in the US have positive work hours assimilation profiles. However, the profile for single male immigrants in comparison to single male natives is steeper than that of married male immigrants in comparison to married male natives. These patterns indicate that if we control for the single-married gap among male natives, then married male immigrants always work less than single male immigrants. In other words, married male immigrants in the US indeed eventually overtake married male natives (as was previously reported in Blau et al., 2003), but for reasons other than the financing of their investment by their wives.

\footnotetext{
${ }^{5}$ The patterns are reversed if the wife is the primary worker and the husband is the secondary worker.
} 
For females, we find that both single and married immigrants work less than their native counterparts, such that the Dif-in-Dif work hours estimator is negative upon arrival, but has a positive slope. This finding contradicts the FIH and implies that immigrant wives do not work more hours upon arrival (in comparison to single female immigrants) in order to finance their husbands' investment.

For Israel, if we control for the work hours gap between married and single female natives, immigrant wives work less hours upon arrival than single female immigrants, but within three years this is reversed. This pattern implies that immigrant wives do not work more hours upon arrival in order to finance their husbands' investment. The Dif-in-Dif work hours estimator for males in Israel has a similar trend but a lower magnitude than for females. In addition, it was found that the wages of immigrant husbands (wives) do not converge to that of native- Israeli husbands (wives). However, the wages of both male and female single immigrants overtake those of their single native counterparts. Thus, if we control for the wage gap between married and single natives, then both immigrant wives and immigrant husbands earn less than their single immigrant counterparts, regardless of how long they have been in Israel. This result suggests that immigrant wives do not finance their husbands' investment (or vice versa), thus contradicting the FIH.

\section{Data}

\section{US}

We examine the labor market assimilation patterns of married and single immigrants in the US using a pooled sample of native couples, immigrant couples, single natives and single immigrants. ${ }^{6}$ The entire 5\% Public Use Samples of the 1980 and 1990 Censuses are used to construct the immigrant samples (couples and singles) while the 1\% Public Use Samples of the 1980 and 1990 Censuses are used to construct the samples of single natives and couples in which both spouses are natives. $^{7}$

As pointed out in Blau et al. (2003), the US Census is particularly suitable for analyzing immigrant outcomes due to its large sample size and its information on race and ethnicity, country of origin and year of immigration (grouped).

In order to compare the Dif-of-Dif results to those of the conventional approach, we adopted the sample restrictions suggested by Blau et al. (2003) and use similar specifications as much as possible. Thus, we restrict the samples of native and immigrant couples to those in which

\footnotetext{
${ }^{6}$ We did not include "mixed couples" in the sample, i.e. those with one immigrant spouse and one native spouse.

${ }^{7}$ We use the $5 \%$ censuses to construct the sample of (married and single) immigrants in order to increase the number of observations on immigrants. Observations are unweighted throughout the analysis.
} 
both spouses are aged 16-64 and exclude the self-employed and individuals with positive but implausible values for their hourly wages (in our case, less than \$1 or greater than \$250 in fixed 2000 dollars using the Personal Consumption Expenditures deflator). We exclude natives born abroad, at sea or in US territories, individuals who are in the military and those with allocated wage and salary income. Note that for married couples, if one spouse did not meet the sample inclusion restrictions, then both were excluded. The samples of single natives and immigrants are based on the same inclusion restrictions as the samples of couples, with the exception that we restrict the age of singles to 21-64 and exclude singles that are classified in the census as children in relation to the head of the household.

\section{Israel}

The analysis for Israel is based on repeated cross-section data from the matched Israeli Labor Force Survey (LFS) and Income Survey (IS) for the years 1991-2004. ${ }^{8}$ The LFS and IS are annual surveys conducted by the Israeli Central Bureau of Statistics. An individual is classified as a native Israeli if he was born in Israel and as an immigrant if he was born in the FSU. Hence, not all immigrants in Israel were included in the analysis. The sample restriction rules in this case are similar to those used for the US data. In other words, we include only native and immigrant couples in which both spouses are aged 16-64 while single natives and immigrants are restricted to ages 21-64.

\section{The Labor Supply and Wage Assimilation of Single and Married Immigrants in the US and Israel}

In order to analyze labor supply, we estimate the following equation separately for females and males using the pooled sample (of married and single immigrants and married and single natives):

$$
\begin{aligned}
& Y_{i t}=\beta X_{i t}+\sum \gamma C_{i}+\sum \gamma^{s} C_{i}^{s}+\alpha_{1} Y_{S M}+\alpha_{2} Y M^{2}{ }_{i t}+\alpha_{3} \text { Married }_{i}+\alpha_{4} Y_{S M} \times \text { Married }_{i}+ \\
& \alpha_{5} \text { YSM }^{2}{ }_{\text {it }} \times \text { Married }_{i}+\alpha_{6} \text { immig }_{i} \times \text { Married }_{i}+\alpha_{7} \text { Age }_{i} \times \text { Married }_{i}+ \\
& \alpha_{8} \text { Age }_{i}{ } \times \text { Married }_{i}+\alpha_{9} \text { child_a } a_{i} \times \text { Married }_{i}+\alpha_{10} \text { child_ }_{b_{i}} \times \text { Married }_{i}+ \\
& \alpha_{11} \text { child_a } a_{i} \times \text { immig }_{i}+\alpha_{12} \text { child_ } b_{i} \times \text { immig }_{i}+\alpha_{13} Y S M_{i t}^{s}+\alpha_{14} Y S M_{i t}^{s^{2}}+\delta K_{t}+u_{i t}
\end{aligned}
$$

where $\mathrm{Y}$ is annual hours worked in the previous year (regular weekly number of hours multiplied by weeks worked, including individuals who worked at home) for individual $i$ in year $t, C_{i}$ is a set of immigrant cohort-of-arrival effects and YSM is years since migration for immigrants (and equals

\footnotetext{
${ }^{8}$ The matched LFS and IS for 1994 was not made available to us.
} 
0 for natives). The sum of an individual i's cohort dummies in equation (1) is identical to the immigrant dummy variable, immig, which therefore is not included separately in (1). To further explore differences between single and married individuals (both natives and immigrants), Equation (1) includes a dummy for married individuals (Married) and interaction terms between this dummy and the following variables: 1) years since migration (YSM), 2) years since migration squared $\left(\mathrm{YSM}^{2}\right)$, 3) a dummy for immigrants (Immig), 4) age (Age), 5) age squared (Age $\left.\left.{ }^{2}\right), 6\right)$ a dummy for the presence of children aged 0-5 (child_a) and 7) number of children (child_b). We allow the effect of the presence of young children and the number of children to differ between immigrants and natives by including interaction terms of the immigrant dummy, immig, with child_a and child_b. $C_{i}^{s}$ is the set of the spouse's cohort-of-arrival effects and $Y S M_{i t}^{s}$ is the spouse's years since migration. ${ }^{9}$ The repeated cross-sections and the assumption of a common time effect for immigrants and natives, $K_{t}$, makes it possible to separately identify immigrant cohort and assimilation effects (Borjas, 1985). Finally, $X$ is a vector of control variables which will be discussed below and $u$ is an error term.

The logged wage equations have a similar form as (1). Real wages for the US were defined as the previous year's wage and salary income divided by weeks worked and multiplied by the regular weekly work hours and expressed in dollars and 2000 prices, while the real wage in Israel was expressed in NIS and 1997 prices.

\section{Specific Parameterization for the US}

The US data was taken from two censuses, such that $t=1980,1990$. The cohort-of-arrival dummy variables (whose coefficients are $\gamma_{s}$ ) were defined so as to include every possible arrival cohort as coded in the Census: 1987-90, 1985-86, 1982-84, 1980-81, 197579, 1970-74, 1965-69, 1960-64, 1950-59 and pre-1950. ${ }^{10}$

The $X$ vector for the US includes quadratics in age for both husband and wife, dummies for years of schooling for both husband and wife, extent of fluency in English (speaks English "well," “poorly” or "not at all”, with native English speakers as the omitted category), number of children, a dummy variable for the presence of children less than six years old, three race/ethnicity dummy

\footnotetext{
${ }^{9}$ As mentioned above, the sum of own-cohort dummies is equal to an immigrant dummy. However, since our sample includes only immigrant couples in which both spouses are immigrants and in equation (1) we include an interaction term between Immig and Married, one of the spouse's cohort dummies had to be dropped.

${ }^{10}$ Following Borjas (1995), we calculated years since migration by evaluating the period-of-immigration variables at their midpoints and used YSM=40 years in 1990 and YSM=30 years in 1980 for the open-ended category (i.e. before 1950).
} 
variables (black, other nonwhite and white), a dummy for Hispanic origin and a metropolitan area dummy variable. ${ }^{11}$ The reference group according to this specification is black single natives with 1-8 years of schooling.

\section{Specific Parameterization for Israel}

The Israeli data were taken from the matched LFS and IS for 1991-2004 such that $t=1991$-1993 and 1995-2004. The cohort dummies for FSU immigrants were 2002, 2001, 2000, 1999, 1998, 1997, 1996, 1995, 1994, 1993, 1992, 1991, 1990, 1980-1989, 1970-1979, 1960-1969, 1950-1959 and pre-1950. The $X$ vector for Israel includes quadratics in age for both husband and wife, dummies for years of schooling for both husband and wife, number of children and a dummy for the presence of children less than six years old. The reference group is single Israeli natives with 18 years of schooling.

\section{Results for the US}

Table 1a presents the basic regression results for annual work hours and wages using reduced form models for the US. Consider first the results for the labor supply equation for females. The results indicate that the annual work hours of a single female immigrant increase during her first nine years in the US and subsequently decline. The single female immigrant's own-cohort effects are positive if she arrived before 1974 and negative otherwise. For a married female immigrant, the effect of her time in the US (in comparison to a married native) equals the sum of the coefficients of YSM, YSM ${ }^{2}$, Married*YSM and Married*YSM${ }^{*}$, which increases for the first 20.5 years. However, the labor supply of an immigrant wife decreases with her husband's time in the US. The own-cohort effect for an immigrant wife is equal to the sum of the coefficients of the cohort dummy and the Married*Immig variable and thus is always negative. Relative to the omitted husband cohort (87-90), the husband's cohort effect on his wife's labor supply is negative if he arrived before 1964 and positive otherwise.

For males, the annual work hours of a single male immigrant increase during his first 31 years in the US and his own-cohort effect is negative with the exception of the 1985-86 cohort. The own-YSM effect for an immigrant husband (YSM, YSM ${ }^{2}$, Married $^{*} Y S M$ and Married ${ }^{*} Y S M^{2}$ ) also increases during his first 30 years in the US and his own-cohort effect is always positive (the sum of the coefficients of the cohort dummy and Married*Immig). The effect of an immigrant wife's time in the US on her husband's labor supply is negative, while the impact of her cohort on his labor supply is positive, relative to the omitted category of wives who arrived in 1987-90.

\footnotetext{
${ }^{11}$ We were not able to use regional dummies as in Blau et al. (2003).
} 
The net effects of YSM and cohort on the work hours assimilation profiles of married immigrants relative to married natives and of single immigrants relative to single natives are presented in Table $1 \mathrm{~b}$ for males and females. The example is based on immigrants (single and married) who arrived between 1975 and 1979 with no children. Relative to single female natives with similar characteristics, we find that immigrant females supply 100.75 fewer work hours upon arrival and tend to supply less work hours as time in the US increases, while immigrant wives supply 346.5 (i.e. -269.04-100.75+23.28) fewer hours upon arrival than married native females with similar characteristics and their labor supply increases over time.

Figure 1a presents the work hours assimilation profiles of female immigrants as they appear in Table 1b. The assimilation effects for single female immigrants imply a concave annual work hours profile relative to comparable single natives, such that the gap at first declines and only increases after nine years in the US. The assimilation effects for married female immigrants imply increasing annual work hours relative to comparable married natives. However, immigrant wives do not overtake native wives. The resulting Dif-in-Dif work hours profile for females is presented in Figure 1c. This profile increases with time in the US and implies that if we control for the work hours gap between married and single female natives, then married female immigrants supply less work hours upon arrival than single female immigrants; however, after somewhat less than 18 years in the US, married female immigrants overtake single female immigrants. This pattern contradicts the FIH and may indicate that immigrant wives invest in their own human capital upon arrival rather than invest in their husbands' human capital.

For males, we find that single immigrants supply 226.1 fewer work hours upon arrival relative to US single natives with similar characteristics, while immigrant husbands supply 267 fewer hours than their native counterparts. As illustrated in Figure 1b, the assimilation effects for single males imply that their annual work hours relative to comparable single male natives increase with time in the US and that they overtake single natives after eight years. The assimilation effects for married males also imply increasing annual work hours relative to comparable married natives and that they overtake native husbands after about 11 years.

Using the Dif-in-Dif approach for males' work hours (Figure 1c), we obtain that married male immigrants supply 40 fewer work hours upon arrival than single male immigrants and in general this gap grows (in absolute terms) with time in the US. In other words, if we control for the work hours gap between married and single male natives, then single male immigrants always supply more work hours than comparable married male immigrants, which contradicts the FIH. 
It is important to note at this point that when using the conventional method to test the FIH the observation that an immigrant husband initially works fewer hours but eventually overtakes his married native counterpart is viewed as support for the FIH. However, according to our Dif-in-Dif strategy this observation alone can not provide a support to the hypothesis and since the work hours gap between immigrant and native single males grows at a faster pace over time than the gap between married male immigrants and natives the FIH is rejected. Hence, married male immigrants in the US indeed eventually work more hours in comparison to married male natives (as was previously reported in Blau et al., 2003), but not because their wives financed their investment in human capital.

With respect to wages, Table 1a indicates that the wage assimilation profiles are positive for immigrant husbands and wives and for single male and female immigrants. The evaluation of these results for the 1975-79 cohort is presented in Table 1c and in Figure 1d for females and in Figure 1e for males. Both married and single female immigrants earn less than their native female counterparts upon arrival in the US, but within somewhat less than five years single female immigrants earn more than single female natives and after about nine years immigrant wives earn more than comparable native wives (Figure 1d). For males (see Figure 1e), we find that single immigrants initially earn 4\% more than single natives, while immigrant husbands earn about $6.3 \%$ less than native husbands. However, both single and immigrant husbands have positive wage assimilation profiles, such that after 20 years in the US single male immigrants earn about $11 \%$ more than single male natives and immigrant husbands earn $20 \%$ more than their native counterparts.

The Dif-in-Dif wage estimator for males and females is presented in Figure 1f and shows that if we control for the wage gap between married and single natives, both immigrant wives and husbands start with lower wages than their single immigrant counterparts, but overtake them in about 9-10 years. In other words, immigrant husbands experience higher wage growth than single male immigrants and similarly immigrant wives experience higher wage growth than single female immigrants. The observation that immigrant wives experience positive wage growth in comparison to single female immigrants indicates that immigrant wives in the US do not take "dead-end" jobs to finance their husbands' investment, but rather invest in their own human capital.

\section{Results: Israel}

The regressions results for annual work hours and wages in Israel are presented in Table 2a. The results show that the annual work hours of a single female immigrant from the FSU increase with 
her time in Israel up to 33 years. Almost all the own-cohort effects are negative and significant relative to the omitted group of 2003-2004. ${ }^{12}$ The change in the labor supply of a married female immigrant with respect to her time in Israel is the sum of the coefficients of $Y S M, Y S M^{2}$, Married*YSM and Married ${ }^{*} Y S M^{2}$, which increases for the first 29 years. The labor supply of an immigrant wife also increases with her husband's time in Israel. The own-cohort effect for an immigrant wife is equal to the sum of the coefficients of her cohort dummy and the Married*Immig variable, implying that it is always negative, while her husband's cohort effect is usually positive, though not always significant relative to the omitted cohort of 2003-2004.

For male immigrants in Israel, the results indicate that the labor supply of a single immigrant increases during his first 44 years in Israel, while the labor supply of a married immigrant increases with his own time in Israel for the first 39 years and also with his wife's time in Israel. The own-cohort effects for male FSU immigrants in Israel who arrived in the waves of immigration during the period 1950-1989 and in the early 1990s are negative and significant relative to the omitted category (2003-2004), while for later periods they switch signs and are usually not significant.

The work hours assimilation profiles for single and married male (female) immigrants who arrived in 1990 and were 30 (28) years old upon arrival in Israel are shown in Table 2b. For females, the results show that both married and single immigrants have positive work hours assimilation profiles relative to their native female counterparts. Upon arrival, immigrant wives supply 356 less hours than comparable native wives, but after five years the situation is reversed, while single female immigrants initially work 216 hours less than comparable single female natives but after 10 years overtake them (see also Figure 2a).

The resulting work hours Dif-in-Dif estimator for females is presented in Figure 2c. If we control for the work hours gap between married and single female natives, we obtain that immigrant wives supply 140 less work hours than comparable single female immigrants. However, this gap is closed after about three years and after twenty years in Israel immigrant wives work approximately 460 hours more than single immigrants. This pattern implies that immigrant wives do not work more hours upon arrival to finance their husbands' investment in human capital.

For males, we also find that both married and single immigrants have positive work hours assimilation profiles relative to their native male counterparts (Table 2a and Figure 2b). Upon arrival, immigrant husbands supply 566 less work hours than comparable native husbands, but

\footnotetext{
${ }^{12}$ The numbers of immigrants (and consequently the number of observations) for the 1999, 2000, 2001 and 2002 cohorts are relatively small and may affect the significance of these variables.
} 
after nine years the situation is reversed. The assimilation hours profile of single male immigrants is almost identical to that of single female immigrants. Single male immigrants initially work 188 hours less than comparable single male natives but after about nine years the situation is reversed.

If we use the Dif-in-Dif work hours estimator for males and thus control for the work hours gap between married and single native males, then the assimilation profile of immigrant husbands relative to comparable single male immigrants is positive and concave (Figure 2c). Immigrant husbands supply 378 less hours than comparable single male immigrants upon arrival, though within 20 years in Israel they are supplying 150 hours more. Although this result may be consistent with the FIH, as mentioned above, the Dif-in-Dif work hours profile of females does not support the hypothesis.

The wage results for males and females in Israel are presented in Table 2a and are illustrated for the 1990 cohort in Table 2c. The illustration is also presented for females in Figure 2d and for males in Figure 2e. Interestingly, we find that although the wage assimilation profile of husbands and wives in immigrant families is positive relative to their native counterparts, the wages of immigrant husbands (wives) do not converge to those of native husbands (wives). However, we find that single female immigrants overtake single female natives after 23 years in Israel and single male immigrants overtake single male natives after 18 years.

Figure $2 \mathrm{f}$ presents the Dif-in-Dif wage profile for females and males in Israel, which shows that when controlling for the wage gap between married and single natives, both immigrant wives and immigrant husbands earn less than their single immigrant counterparts, regardless of time in Israel. This result suggests that immigrant wives in Israel do not finance their husbands' investment in human capital (or vise versa) and thus contradicts the FIH.

\section{Conclusions}

The paper offers an alternative method for testing the Family Investment Hypothesis. The estimation is based on comparing the labor supply and wage patterns of married and single immigrants. To account for the possible self-selection to marry as a result of unobserved characteristics that may also affect labor outcomes, we exploited the variation in the labor supply and wages of married and single natives and constructed a difference in differences (Dif-in-Dif) estimator in order to test the FIH.

The estimation was carried out using micro data for the US and Israel. The use of the Israeli data on immigrants from the Former Soviet Union adds additional novel aspect to the 
analysis since it allows us to test the FIH among highly-skilled immigrants, for whom the need to invest in local human capital is crucial.

According to the results for both countries, the FIH is to be rejected. By controlling for the labor supply gap between married and single female natives, it was shown that immigrant wives in the US and in Israel work less than single female immigrants upon arrival, but eventually overtake them. In addition, we find that by controlling for the wage gap between married and single female natives, immigrant wives in the US and in Israel earn less than single female immigrants upon arrival; while according to the FIH they should have earned more in order to finance the family current consumption.

Finally, the paper demonstrates that the conventional testing of the FIH based on a comparison between married immigrants and married natives can be misleading. We show that although immigrant husbands in the US indeed overtake native husbands in labor supply, single male immigrants also overtake single male natives and by an even greater percentage.

Thus, the positive work hours assimilation of immigrant husbands cannot be attributed to the financial support of their wives, but is apparently due to other factors. Exploring these factors awaits further empirical investigation. 
Table 1a: Work Hours and Wage Regressions for the US

\begin{tabular}{|c|c|c|c|c|c|c|c|c|}
\hline \multirow{4}{*}{$\begin{array}{l}\text { Independent } \\
\text { Variable }^{\mathrm{a}}\end{array}$} & \multicolumn{4}{|c|}{ Annual work hours } & \multicolumn{4}{|c|}{ Wage } \\
\hline & \multicolumn{2}{|c|}{ female } & \multicolumn{2}{|c|}{ male } & \multicolumn{2}{|c|}{ female } & \multicolumn{2}{|c|}{ male } \\
\hline & & Standard & & Standard & & Standard & & Standard \\
\hline & Coefficient & Error & Coefficient & Error & Coefficient & Error & Coefficient & Error \\
\hline Ysm_f & 5.30249 & 1.074562 & -17.3908 & 1.159352 & 0.003737 & 0.00112 & 0.002947 & 0.001072 \\
\hline $\mathrm{Ysm}^{\overline{2}} \mathrm{f}$ & -0.30545 & 0.027641 & 0.227669 & 0.028317 & 2.47E-05 & 3.05E-05 & 1.69E-05 & 2.76E-05 \\
\hline Ysm_m & -4.31294 & 1.173328 & 28.78018 & 0.946155 & 0.001765 & 0.001234 & 0.001609 & 0.000946 \\
\hline $\mathrm{Ysm}^{\overline{2}} \mathrm{~m}$ & 0.125163 & 0.025945 & -0.45686 & 0.026247 & $-6.8 E-05$ & 2.86E-05 & 8.97E-05 & $2.72 \mathrm{E}-05$ \\
\hline Marriēd & 2281.753 & 16.23594 & 1202.788 & 15.83343 & 0.376473 & 0.018187 & -0.09559 & 0.016296 \\
\hline Married*immig & -269.045 & 11.217 & -207.51 & 9.744088 & -0.07863 & 0.012082 & -0.08965 & 0.009033 \\
\hline Married*Ysm & 22.39715 & 1.054567 & 18.80833 & 1.002803 & 0.008164 & 0.001126 & 0.010507 & 0.000971 \\
\hline Married* $^{*} s^{2}$ & -0.37047 & 0.024723 & -0.32994 & 0.023841 & -0.00011 & $2.81 \mathrm{E}-05$ & -0.00018 & $2.51 \mathrm{E}-05$ \\
\hline im50_f & 417.2411 & 30.71052 & 329.7701 & 35.10657 & -0.12617 & 0.031531 & -0.14912 & 0.03422 \\
\hline im505̄ & 95.19205 & 18.81836 & 384.7057 & 20.49345 & -0.05934 & 0.018511 & -0.04901 & 0.019047 \\
\hline im6064_f & 57.94284 & 15.38421 & 364.2234 & 16.5663 & -0.02368 & 0.01516 & -0.03709 & 0.015182 \\
\hline im6569_f & 35.53389 & 12.97162 & 325.0767 & 13.8236 & 0.006074 & 0.013072 & -0.0355 & 0.012685 \\
\hline im7074_f & 15.29503 & 10.89743 & 276.7168 & 11.46749 & 0.008235 & 0.011207 & -0.02685 & 0.010495 \\
\hline im7579_f & -100.757 & 8.354597 & 166.6367 & 9.174648 & -0.01897 & 0.008914 & -0.02851 & 0.00842 \\
\hline im8081_f & -71.2592 & 10.16169 & 112.6677 & 10.89608 & -0.03574 & 0.010282 & -0.04443 & 0.009708 \\
\hline im8284_f & -105.194 & 9.701989 & 88.42153 & 10.58828 & -0.04094 & 0.009736 & -0.04115 & 0.00934 \\
\hline im8586_f & -176.767 & 9.271906 & 41.16765 & 10.39708 & -0.05978 & 0.0093 & -0.0318 & 0.00909 \\
\hline im8790_f & -471.238 & 7.895697 & & & -0.09466 & 0.008109 & & \\
\hline im50_m & -114.25 & 33.99992 & -258.094 & 28.65291 & 0.030725 & 0.035499 & -0.11311 & 0.028268 \\
\hline im5059_m & -83.57 & 21.92537 & -419.829 & 16.68214 & -0.02543 & 0.022305 & -0.03925 & 0.015981 \\
\hline im6064_m & -65.4375 & 18.36593 & -370.191 & 13.46419 & -0.02281 & 0.01878 & 0.014644 & 0.012866 \\
\hline im6569_m & 10.14554 & 15.6951 & -329.555 & 11.32961 & -0.00911 & 0.016257 & 0.043747 & 0.011037 \\
\hline im7074_m & 27.90518 & 13.32865 & -232.813 & 9.476387 & 0.00027 & 0.014032 & 0.057564 & 0.009328 \\
\hline im7579_m & 23.28002 & 11.14634 & -226.103 & 7.02837 & 0.001935 & 0.012093 & 0.040101 & 0.007263 \\
\hline im8081_m & 35.60013 & 12.25543 & -100.645 & 9.012312 & -0.01457 & 0.013028 & 0.031029 & 0.008574 \\
\hline im8284_m & 16.97814 & 12.04072 & -21.1462 & 8.50369 & -0.0139 & 0.012814 & 0.038739 & 0.008002 \\
\hline im8586_m & 31.51431 & 12.1391 & 29.34108 & 7.890935 & -0.00493 & 0.013083 & 0.03282 & 0.007366 \\
\hline im8790_m & & & -280.968 & 6.741369 & & & 0.003639 & 0.006569 \\
\hline
\end{tabular}

$a \_\mathrm{m}$ indicates male and_f indicates female. 
Table 1b: Differences in work hours between immigrants and natives by marital status and gender for the US (1975-79 cohort)

\begin{tabular}{|c|c|c|c|c|c|c|c|c|c|}
\hline \multirow[b]{2}{*}{ Group } & \multirow{2}{*}{$\begin{array}{l}\text { Net } \\
\text { YSM }\end{array}$} & \multirow{2}{*}{$\begin{array}{l}\text { Net } \\
\text { YSM }^{2}\end{array}$} & \multicolumn{7}{|c|}{ Difference between immigrants and natives evaluated at YSM = } \\
\hline & & & 0 & 5 & 10 & 15 & 20 & 25 & 30 \\
\hline \multicolumn{10}{|l|}{ (1) Difference: } \\
\hline $\begin{array}{l}\text { Married Females - } \\
\text { Immigrant vs, Native }\end{array}$ & $23.3^{\mathrm{a}}$ & 0.550 & -346.5 & -243.35 & -167.73 & -119.64 & -99.09 & -106.07 & -140.60 \\
\hline \multicolumn{10}{|l|}{ (2) Difference: } \\
\hline $\begin{array}{l}\text { Single Females - } \\
\text { Immigrant vs. Native }\end{array}$ & 5.3 & 0.305 & -100.75 & -81.88 & -78.27 & -89.94 & -116.88 & -159.10 & -216.58 \\
\hline \multicolumn{10}{|l|}{ Females } \\
\hline \multicolumn{10}{|l|}{$\begin{array}{l}\text { Dif-in-Dif } \\
\text { (1)-(2) }\end{array}$} \\
\hline & & & -245.75 & -161.47 & -89.46 & -29.7 & 17.79 & 53.03 & 75.98 \\
\hline \multicolumn{10}{|l|}{ (3) Difference: } \\
\hline $\begin{array}{l}\text { Married Males - } \\
\text { Immigrant vs. Native }\end{array}$ & $30.2^{\mathrm{a}}$ & 0.559 & -267 & -129.96 & -20.91 & 60.18 & 113.32 & 138.50 & 135.73 \\
\hline \multicolumn{10}{|l|}{ (4) Difference: } \\
\hline Single Males - & & - & & & & & & & \\
\hline Immigrant vs. Native & 28.7 & 0.456 & -226.1 & -93.62 & 16.01 & 102.80 & 166.75 & 207.86 & 226.12 \\
\hline \multicolumn{10}{|l|}{ Males } \\
\hline Dif-in-Dif & & & & & & & & & \\
\hline (3)-(4) & & & -40.9 & -36.34 & -36.92 & -42.62 & -53.43 & -69.36 & -90.39 \\
\hline
\end{tabular}

Notes: Based on regression results reported in Table 1a.

$a$ Net YSM equals the sum of the coefficients of YSM_f, YSM_m and Married*YSM. 
Table 1c: Differences in logged wages between immigrants and natives by marital status and gender for the US (1975-79 cohort)

Net Net $\quad$ Difference between immigrants and natives evaluated at YSM =

\section{(1)} YSM YSM $^{2}$ 0 15 25 30

Difference:

Married

Females -

Immigrant vs.

Native

$\begin{array}{lllllllll}0.0136^{\mathrm{a}} & -0.00015 & -0.0976 & -0.0310 & 0.0261 & 0.0758 & 0.1181 & 0.1530 & 0.1804\end{array}$

(2)

Difference:

Single

Females Immigrant vs.

Native $\begin{array}{lllllllll}0.0037 & 2.47 * 10^{-5} & -0.0189 & 0.0003 & 0.0261 & 0.0426 & 0.0656 & 0.0899 & 0.1154\end{array}$

Females Dif-in-Dif (1)-(2) $-0.0787 \quad-0.0313$ $0 \quad 0.0332$ 0.0525 $0.0631 \quad 0.065$

(3)

Difference:

Married

Males -

Immigrant vs.

Native

$0.0151^{\mathrm{a}} \quad-7.3^{*} 10^{-5} \quad-0.1181 \quad-0.0046 \quad 0.0651$

0.1311

$0.1934 \quad 0.2520$

0.3068

(4)

Difference:

Single Males

Immigrant vs.

Native

0.0016

$8.97 * 10^{-5}$

$-0.0285 \quad 0.0503$

0.0651

0.0844

0.1081

0.1363

0.1691

Males

Dif-in-Dif

(3)-(4)

$-0.0896 \quad-0.0549$

$\begin{array}{llll}0 & 0.0467 & 0.0853 & 0.1157\end{array}$

0.1377

Notes: Based on regression results reported in Table 1a.

$a$ Net YSM equals the sum of the coefficients of YSM_f, YSM_m and Married*YSM 
Table 2a: Work Hours and Wage Regressions for Israel

\begin{tabular}{|c|c|c|c|c|c|c|c|c|}
\hline \multirow[t]{2}{*}{$\begin{array}{l}\text { Independent } \\
\text { Variable }^{\mathrm{a}}\end{array}$} & \multicolumn{4}{|c|}{ Annual hours } & \multicolumn{4}{|c|}{ Wage } \\
\hline & \multicolumn{2}{|c|}{ female } & \multicolumn{2}{|c|}{ Male } & \multicolumn{2}{|c|}{ female } & \multicolumn{2}{|c|}{ male } \\
\hline & & Standard & & Standard & & Standard & & Standard \\
\hline & Coefficient & & Coefficient & Error & Coefficient & Error & Coefficient & Error \\
\hline Ysm_f & 25.75094 & 6.252143 & 32.13046 & 10.15153 & 0.02262 & 0.00503 & 0.012669 & 0.006376 \\
\hline$Y s m^{\overline{2}} f$ & -0.38822 & 0.11472 & -0.80148 & 0.162853 & -0.00038 & 9.98E-05 & -0.00035 & 0.000138 \\
\hline Ysm_m & 20.50237 & 8.488665 & 23.0483 & 6.390822 & 0.02323 & 0.008746 & 0.020721 & 0.004013 \\
\hline $\mathrm{Ysm}^{2}$-m & -0.50002 & 0.120863 & -0.26453 & 0.107101 & -0.00061 & 0.000208 & -0.00023 & 6.19E-05 \\
\hline Marriē & -268.449 & 103.2678 & 144.6366 & 125.6159 & -0.19134 & 0.095006 & -0.48677 & 0.094298 \\
\hline married*immig & -404.417 & 339.7467 & -868.792 & 334.5371 & -0.49387 & 0.284492 & -0.53429 & 0.204599 \\
\hline married*Ysm & 31.18282 & 8.069309 & 14.75183 & 9.018398 & $-5.5 E-05$ & 0.007724 & 0.013581 & 0.00521 \\
\hline married*$^{\star} \mathrm{Ysm}^{2}$ & -0.59214 & 0.144298 & -0.22075 & 0.147534 & 0.000036 & 0.000179 & -0.00014 & 9.4E-05 \\
\hline im_f49 & 34.98233 & 217.1725 & 1549.022 & 527.2796 & 0.100586 & 0.163177 & 0.761855 & 0.357762 \\
\hline im_f59 & -283.713 & 172.4879 & 954.3164 & 438.0796 & -0.11146 & 0.127835 & 0.338301 & 0.275664 \\
\hline im_f69 & -294.457 & 139.6445 & 573.6423 & 404.2893 & -0.25795 & 0.102588 & 0.196613 & 0.246485 \\
\hline im_f79 & -405.109 & 105.7892 & 408.727 & 357.5763 & -0.30581 & 0.079925 & 0.027551 & 0.219095 \\
\hline im_f89 & -321.118 & 78.27584 & 506.565 & 350.0322 & -0.24523 & 0.05984 & 0.038945 & 0.213698 \\
\hline im_f90 & -216.74 & 59.03202 & 490.2956 & 340.7518 & -0.32166 & 0.046229 & -0.09439 & 0.208643 \\
\hline im_f91 & -211.562 & 57.62368 & 403.5436 & 340.5889 & -0.39838 & 0.045213 & -0.07857 & 0.208393 \\
\hline im_f92 & -162.694 & 66.69557 & 382.0504 & 343.6512 & -0.37667 & 0.050303 & 7238 & 0.209806 \\
\hline im_f93 & -155.831 & 70.84341 & 477.0831 & 344.4266 & -0.43865 & 0.052575 & 0.003691 & 0.210315 \\
\hline im_f94 & -171.208 & 64.58447 & 324.0196 & 343.7514 & -0.37008 & 0.047298 & -0.06393 & 0.209831 \\
\hline im_f95 & -212.587 & 68.14863 & 469.8602 & 342.9605 & -0.34997 & 0.050435 & -0.15941 & 0.209804 \\
\hline im_f96 & -195.453 & 70.58081 & 383.9537 & 345.4827 & -0.4124 & 0.05273 & -0.08864 & 0.210896 \\
\hline im_f97 & -21.225 & 74.1157 & 308.7741 & 348.1967 & -0.37772 & 0.052298 & -0.09833 & 0.212345 \\
\hline im_f98 & -211.026 & 89.99068 & 384.7223 & 350.6336 & -0.51327 & 0.069096 & -0.08691 & 0.212782 \\
\hline im_f99 & 48.85163 & 88.89071 & 444.8791 & 353.1134 & -0.40518 & 0.060491 & -0.03017 & 0.21486 \\
\hline im_f100 & 71.97309 & 107.6158 & 556.2577 & 364.5566 & -0.40451 & 0.082557 & 0.055373 & 0.22442 \\
\hline im_f101 & -145.359 & 122.2069 & 147.8725 & 378.256 & -0.45159 & 0.091617 & 0.042951 & 0.232299 \\
\hline im_f102 & 206.3338 & 201.9658 & 1121.202 & 415.786 & -0.40384 & 0.150026 & 0.173218 & 0.246811 \\
\hline im_m49 & 858.8613 & 465.419 & -272.076 & 243.4191 & 0.962793 & 0.402609 & -0.17773 & 0.168121 \\
\hline im_m59 & 139.8661 & 414.0052 & -687.136 & 194.6611 & 0.337703 & 0.343018 & -0.45474 & 0.125384 \\
\hline im_m69 & 216.1996 & 387.7311 & -754.146 & 152.0955 & 0.161196 & 0.314777 & -0.51059 & 0.09636 \\
\hline im_m79 & 86.50895 & 358.7532 & -567.885 & 112.1981 & 0.201788 & 0.297295 & -0.37392 & 0.072413 \\
\hline im_m89 & 308.7341 & 352.1894 & -287.919 & 85.60517 & 0.071687 & 0.292863 & -0.34471 & 0.054239 \\
\hline im_m90 & 264.8444 & 345.2939 & -188.074 & 62.23629 & 0.025007 & 0.288667 & -0.29881 & 0.039735 \\
\hline im_m91 & 206.5277 & 345.1064 & -113.106 & 60.90508 & 0.042049 & 0.288493 & -0.35105 & 0.038077 \\
\hline im_m92 & 295.9543 & 347.4124 & -120.355 & 71.76784 & -0.00811 & 0.289666 & -0.33111 & 0.043339 \\
\hline im_m93 & 314.7047 & 348.0145 & -155.125 & 73.46017 & 0.049995 & 0.289839 & -0.38491 & 0.044939 \\
\hline im_m94 & 345.8384 & 347.2085 & 8.199701 & 72.5072 & 0.056021 & 0.289171 & -0.31484 & 0.043262 \\
\hline im_m95 & 334.1152 & 347.8267 & -90.1841 & 73.7943 & 0.02929 & 0.289827 & -0.24527 & 0.044143 \\
\hline im_m96 & 320.8884 & 348.9754 & -59.4606 & 81.48393 & 0.111096 & 0.29053 & -0.31747 & 0.049353 \\
\hline im_m97 & 74.73281 & 350.1775 & 52.34888 & 87.80086 & 0.108974 & 0.291005 & -0.25342 & 0.052992 \\
\hline im_m98 & 398.5705 & 354.9246 & -72.6088 & 103.0534 & 0.273469 & 0.294411 & -0.23351 & 0.063528 \\
\hline im_m99 & -13.1828 & 353.8811 & -32.5738 & 104.4228 & 0.111138 & 0.292836 & -0.33856 & 0.062615 \\
\hline im_m100 & -84.5437 & 361.7709 & -329.493 & 134.6544 & 0.185378 & 0.300601 & -0.47067 & 0.090783 \\
\hline im_m101 & 140.9658 & 372.1562 & 160.3759 & 164.259 & 0.315476 & 0.306267 & -0.2615 & 0.104517 \\
\hline im_m102 & -37.7414 & 430.1635 & -454.246 & 211.2653 & 0.342365 & 0.349194 & -0.52644 & 0.146787 \\
\hline
\end{tabular}

$a \_\mathrm{m}$ indicates male and $\mathrm{f}$ indicates female. 
Table 2b: Differences in work hours between immigrants and natives by marital status and gender in Israel (1990 cohort)

Net Net Difference between immigrants and natives evaluated at YSM =

Group YSM $\quad$ YSM $^{2}$

10

15

20

25

30

(1) Difference: Married Females Immigrant vs.

Native

$77.43^{\mathrm{a}}-1.48$

$-356$

$-6.14 \quad 270.00$

472.14

600.25

654.34

634.42

(2) Difference: Single Females

-

Immigrant vs.

Native 25.75

$-0.39$

$-216.74 \quad-97.69$

1.94

82.17

142.98

184.39

206.38

Females Dif-in-Dif

(1)-(2)

$$
-139.26
$$

91.55

268.06

389.97

457.27

469.95

428.04

(3) Difference: Married Males Immigrant vs.

Native

$69.93^{\mathrm{a}}$

$-1.29$

$-566 \quad-249.08$

4.06

192.86

317.33

377.47

373.26

(4) Difference: Single Males Immigrant vs.

Native

$-0.26 \quad-188.07$

$\begin{array}{ll}-79.44 & 15.95\end{array}$

$98.13 \quad 167.07$

222.79

265.29

Males

Dif-in-Dif

(3)-(4) $-377.93$ $-169.64$ $-11.89$ 94.73 150.26 154.68 107.97

Notes: Based on regression results reported in Table 2a.

$a$ Net YSM equals the sum of the coefficients of YSM_f, YSM_m and Married*YSM 
Table 2c: Differences in logged wages between immigrants and natives in Israel by marital status and gender (1990 cohort)

\begin{tabular}{|c|c|c|c|c|c|c|c|c|c|}
\hline \multirow[b]{2}{*}{ Group } & \multirow{2}{*}{$\begin{array}{l}\text { Net } \\
\text { YSM }\end{array}$} & \multirow{2}{*}{$\begin{array}{l}\text { Net } \\
\text { YSM }^{2} \\
\end{array}$} & \multicolumn{7}{|c|}{ Difference between immigrants and natives evaluated at YSM = } \\
\hline & & & 0 & 5 & 10 & 15 & 20 & 25 & 30 \\
\hline $\begin{array}{l}\text { (1) Difference: } \\
\text { Married } \\
\text { Females - } \\
\text { Immigrant vs. } \\
\text { Native }\end{array}$ & 0.0458 & -0.00095 & -0.7904 & -0.5854 & -0.4280 & -0.3184 & -0.2566 & -0.2425 & -0.2762 \\
\hline $\begin{array}{l}\text { (2) Difference: } \\
\text { Single Females } \\
\text { - }\end{array}$ & & & & & & & & & \\
\hline $\begin{array}{l}\text { Immigrant vs. } \\
\text { Native }\end{array}$ & 0.0226 & -0.0004 & -0.3216 & -0.2180 & -0.1332 & -0.0674 & -0.0204 & 0.0075 & 0.0166 \\
\hline $\begin{array}{l}\text { Females } \\
\text { Dif-in-Dif } \\
\text { (1)-(2) }\end{array}$ & & & -0.4688 & -0.3674 & -0.2948 & -0.251 & -0.2362 & -0.25 & -0.2928 \\
\hline $\begin{array}{l}\text { (3) Difference: } \\
\text { Married Males } \\
\text {-Immigrant vs. } \\
\text { Native }\end{array}$ & 0.0207 & -0.0002 & -0.9275 & -0.7106 & -0.5296 & -0.3847 & -0.2757 & -0.2027 & -0.1656 \\
\hline $\begin{array}{l}\text { (4) Difference: } \\
\text { Single Males - } \\
\text { Immigrant vs. } \\
\text { Native }\end{array}$ & 0.0469 & -0.00072 & -0.2988 & -0.2010 & -0.1147 & -0.0401 & 0.0228 & 0.0742 & 0.1140 \\
\hline $\begin{array}{l}\text { Males } \\
\text { Dif-in-Dif } \\
\text { (3)-(4) }\end{array}$ & & & -0.6287 & -0.5096 & -0.4149 & -0.3446 & -0.2985 & -0.2769 & -0.2796 \\
\hline
\end{tabular}

Notes: Based on regression results reported in Table 2a.

$a$ Net YSM equals the sum of the coefficients of YSM_f, YSM_m and Married*YSM 


\section{References}

Baker, Michael and Dwayne, Benjamin. 1997. "The Role of the Family in Immigrants' Labor Market Activity: An Evaluation of Alternative Explanations." American Economic Review, 87(4): 705-727.

Beach, Charles .M, and Christopher, Worswick. 1993."Is There a Double-Negative Effect on the Earnings of Immigrant Women?." Canadian Public Policy, 19(1): 36-53.

Blau, Francine .D, Lawrence M. Khan, Joan Y. Moriarty and Andre Portela Souza. 2003. "The Role of the Family in Immigrants' Labor Market Activity: An Evaluation of Alternative Explanations- Comment." American Economic Review, 93(1): 429-447.

Borjas, George .J. 1985."Assimilation, Changes in Cohort Quality, and the Earnings of Immigrants.” Journal of Labor Economics, 3(4): 463-489.

Cobb-Clark, Deborah and Thomas F. Crossley. 2004. "Revisiting the Family Investment Hypothesis." Labour Economics, 11(3) pp. 373-393.

Duleep, Harriet .O, and Daniel, .J, Dowhan. 2002. "Revisiting the Family Investment Model with Longitudinal Data: The Earnings Growth of Immigrant and U.S.-Born Women." Forschunsinstitut zur Zukunft der Arbeit (IZA) Discussion Paper No: 568.

Duleep, Harriet .O, and Seth Sanders. 1993. "The Decision to Work by Married Immigrant Women." Industrial and Labor Relations Revie, 46(4): 67-80.

MacPherson, David, A. and James, B. Stewart. 1989. "The Labor Force Participation and Earnings Profiles of Married Immigrant Females.” Quarterly Review of Economics and Business, 29: 57-72.

Worswick Christopher. 1996. "Immigrant Families in the Canadian Labour Market." Canadian Public Policy, 22(4): 378-396.

Worswick Christopher. 1999. "Credit Constraints and the Labor Supply of Immigrant Families in Canada." Canadian Journal of Economics, 32(1): 152-170. 
Figure 1a: U.S. Work Hours Assimilation Profiles: Married and Single Females, US

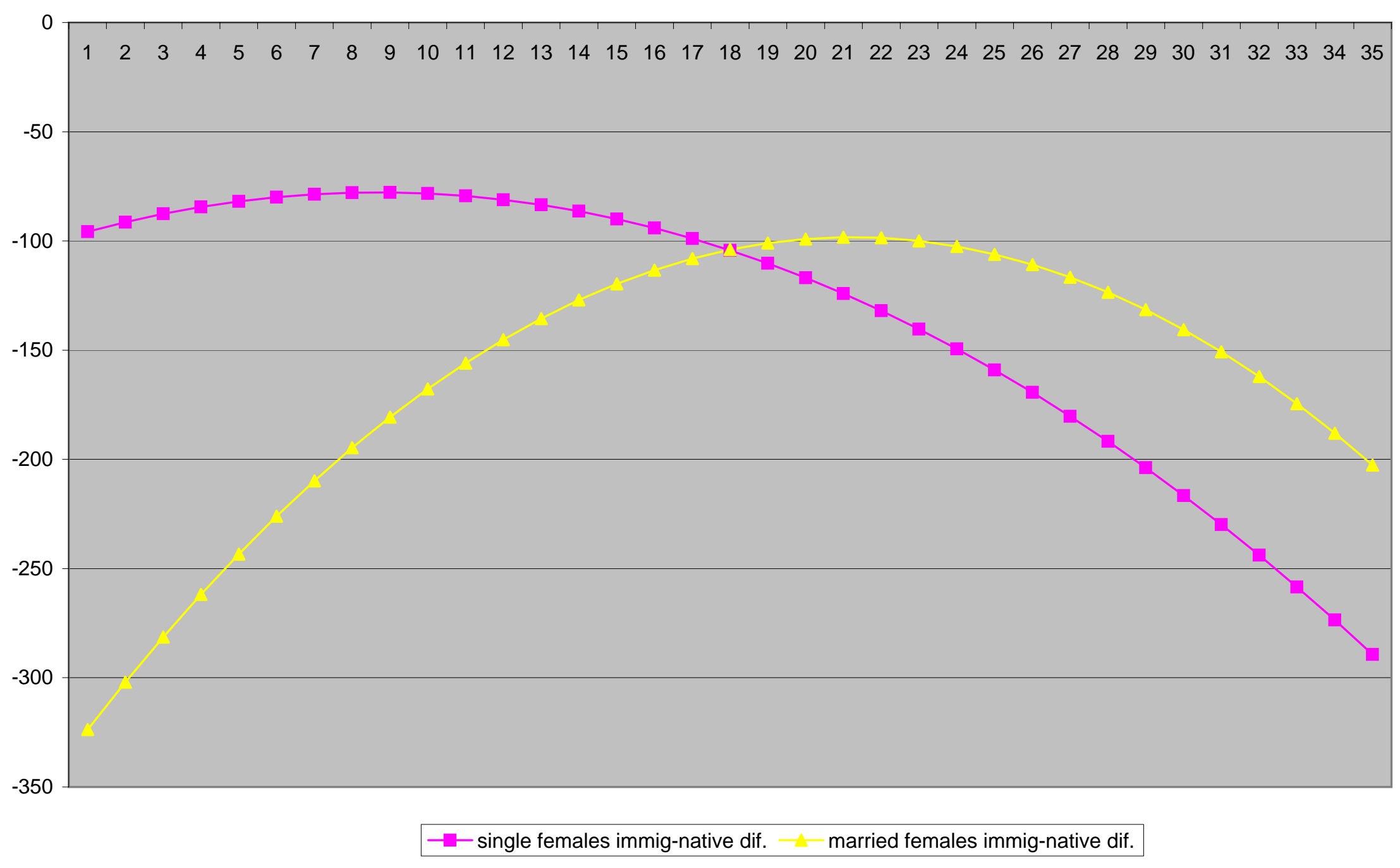


Figure 1b: Work Hours Assimilation Profiles: Married and Single Males, US

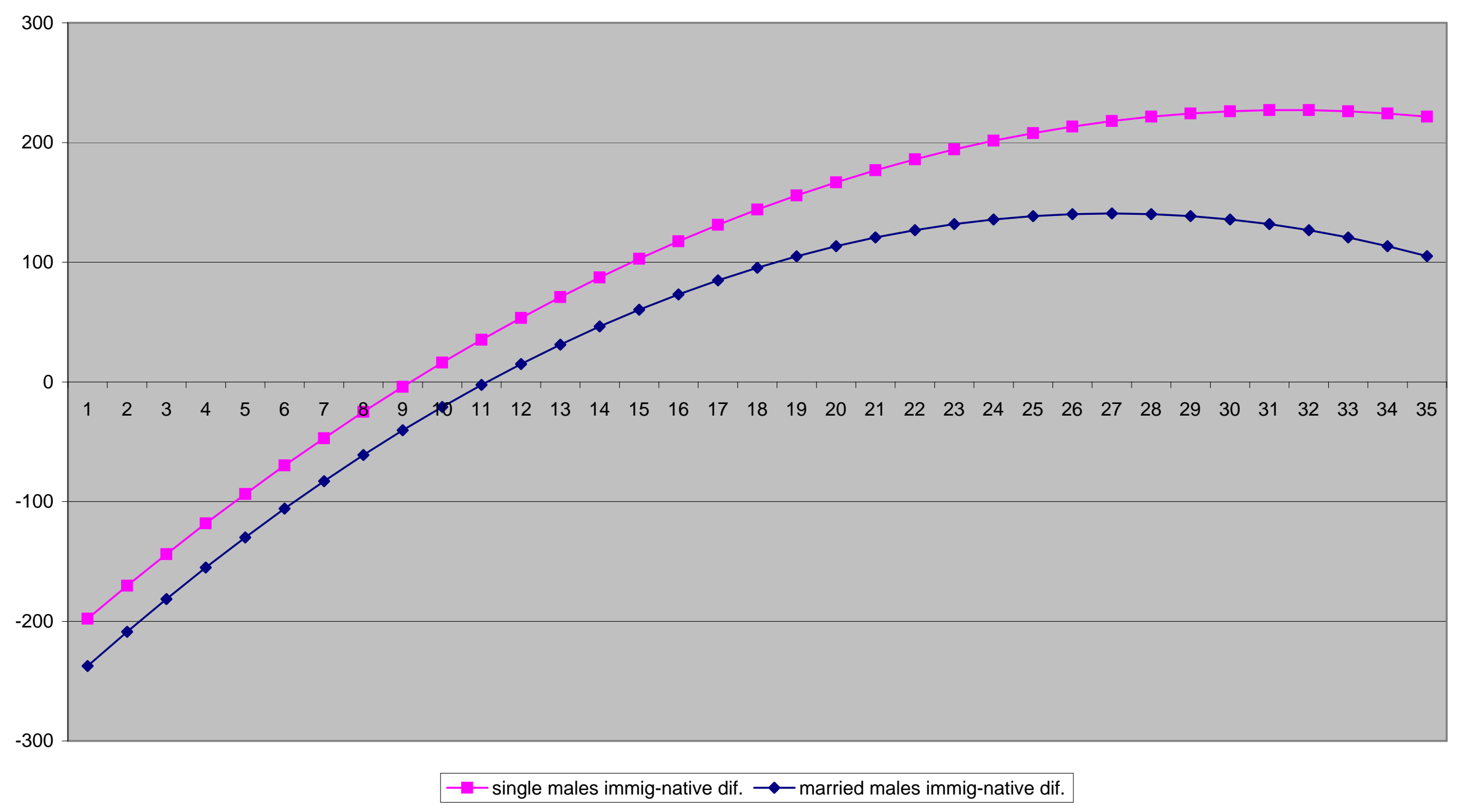


Figure 1c: Work Hours Difference in Differences Profiles, US

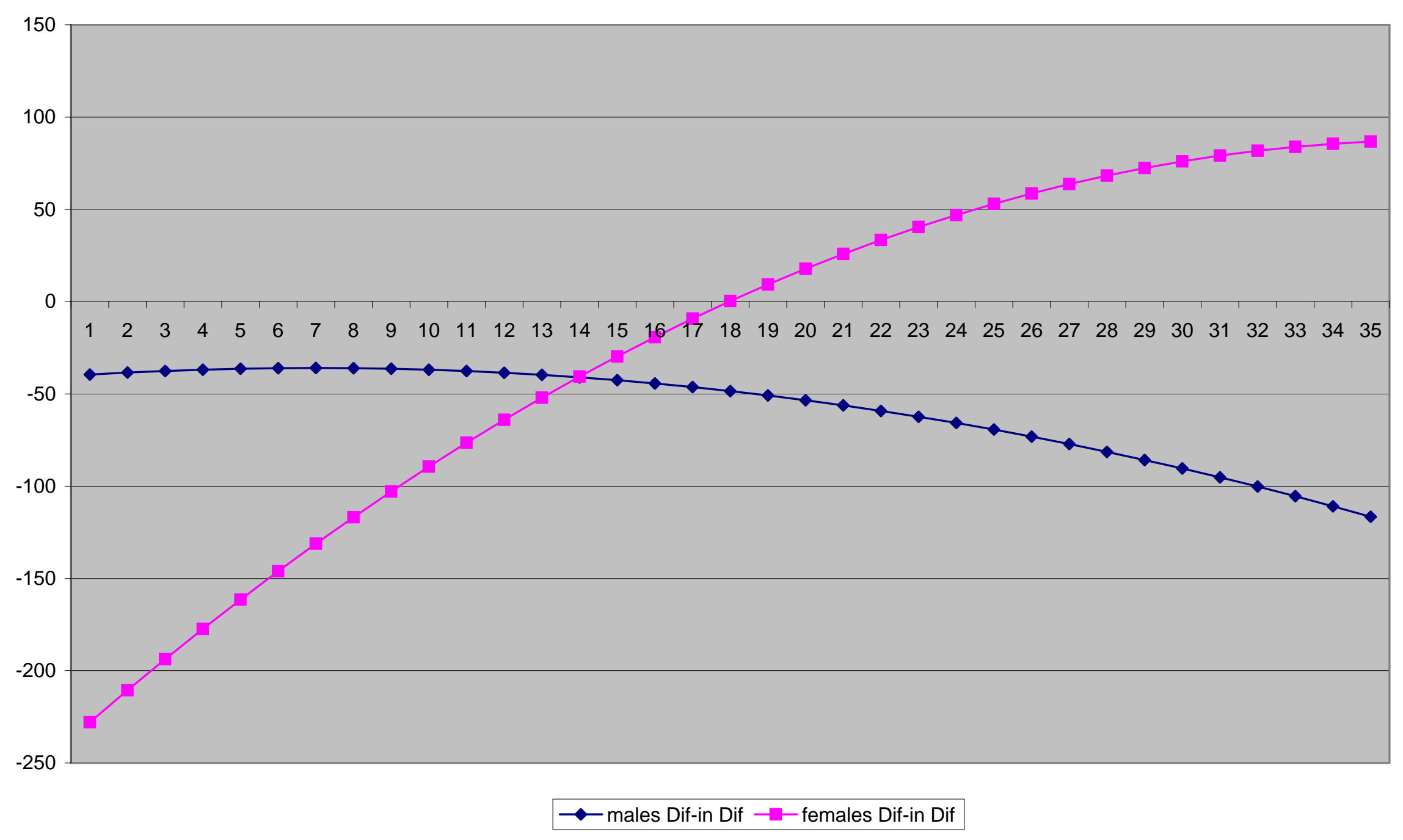


Figure 1d: Wage Assimilation Profiles: Married and Single Females, US

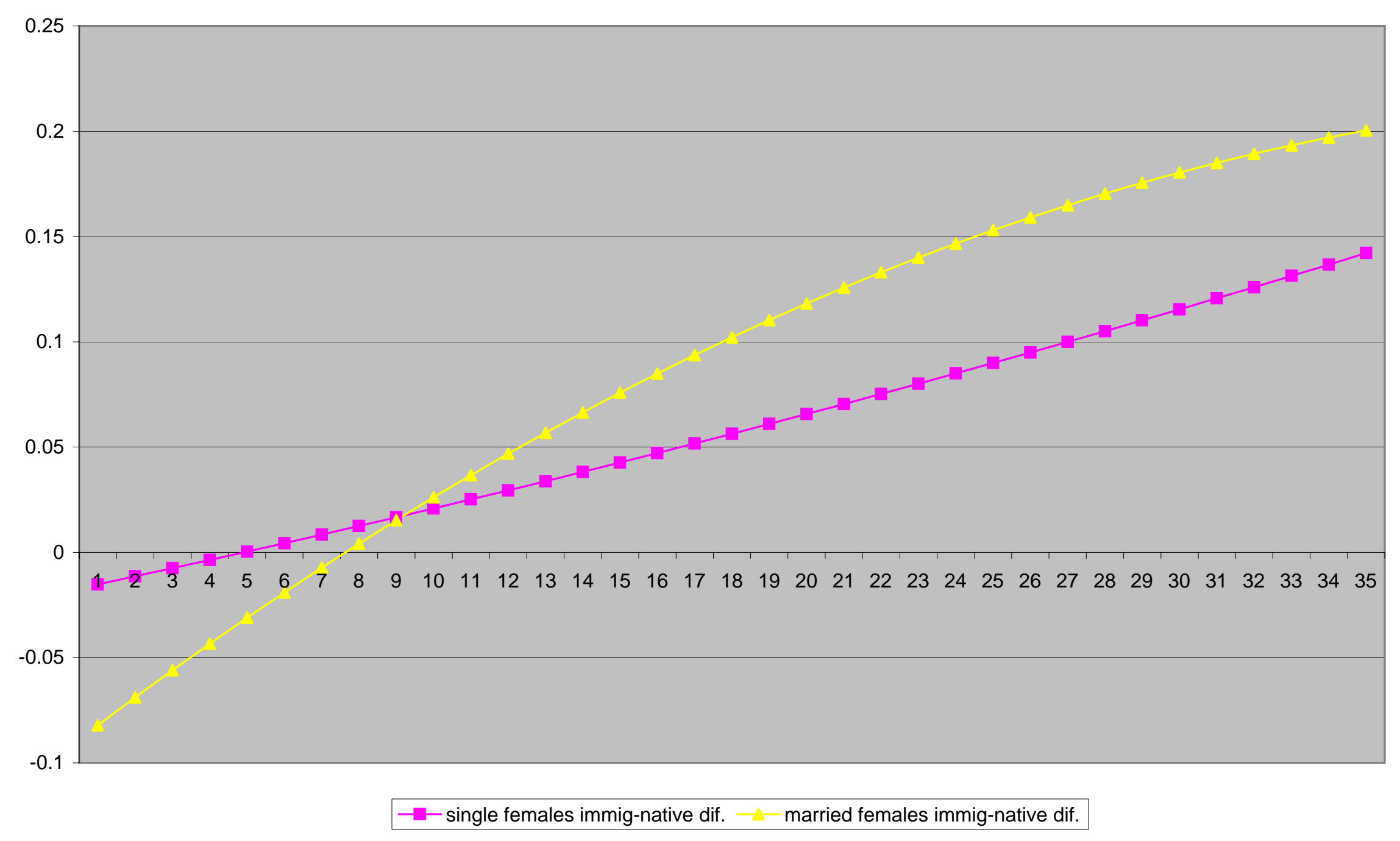


Figure 1e: Wage Assimilation Profiles: Married and Single Males, US

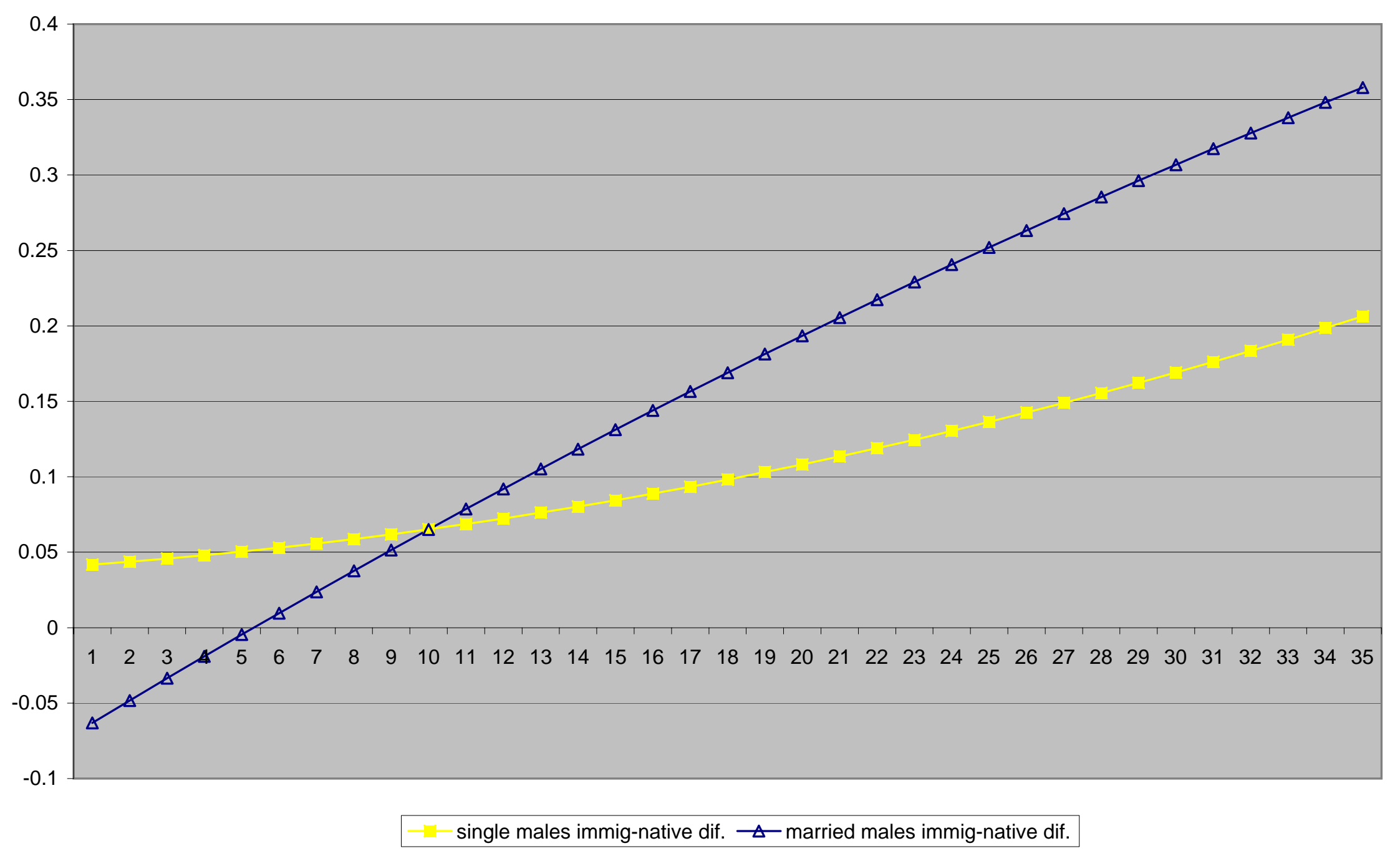


Figure 1f: Wage Difference in Differences Profiles, US

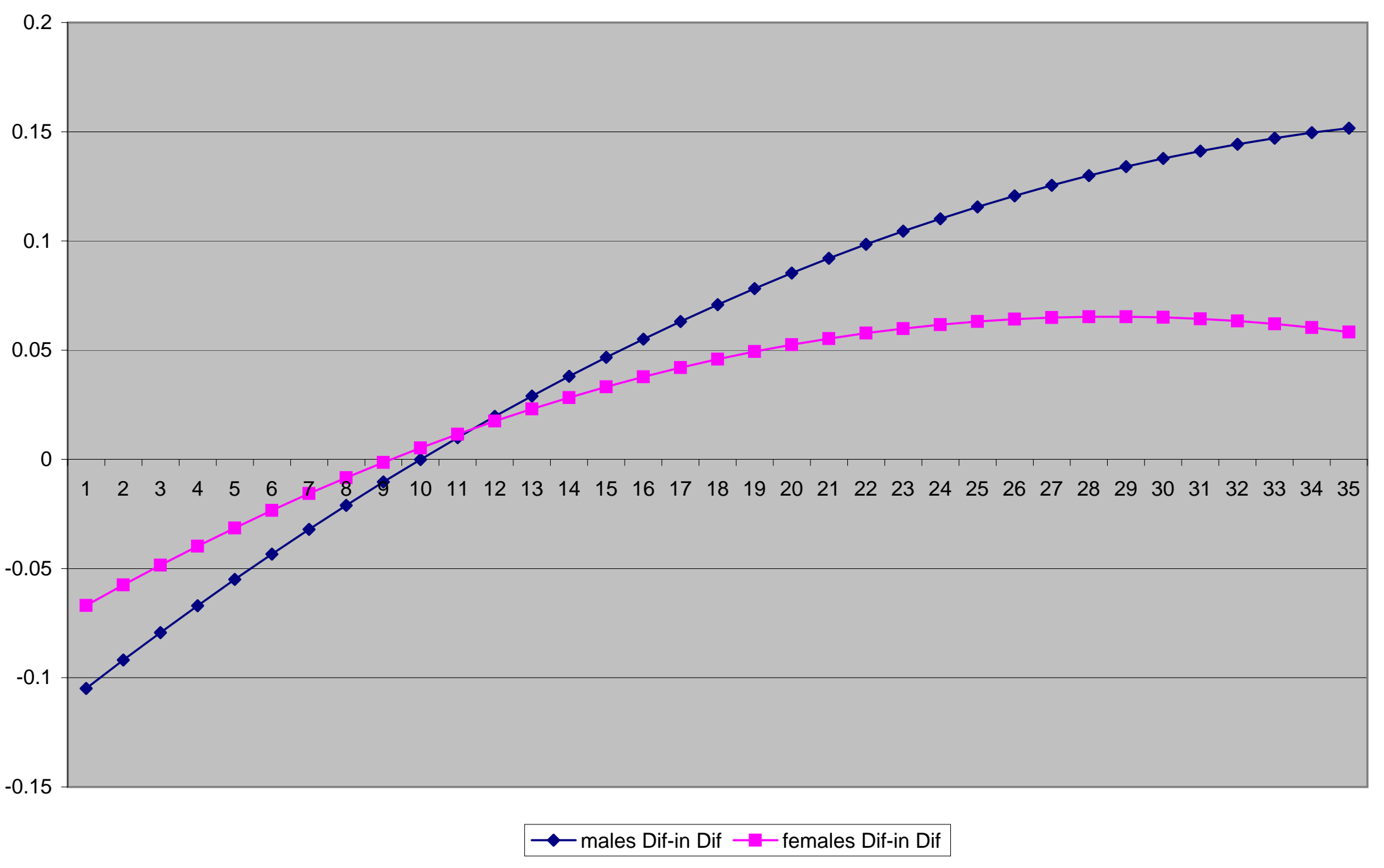


Figure 2a: Work Hours Assimilation Profiles: Married and Single Females, Israel

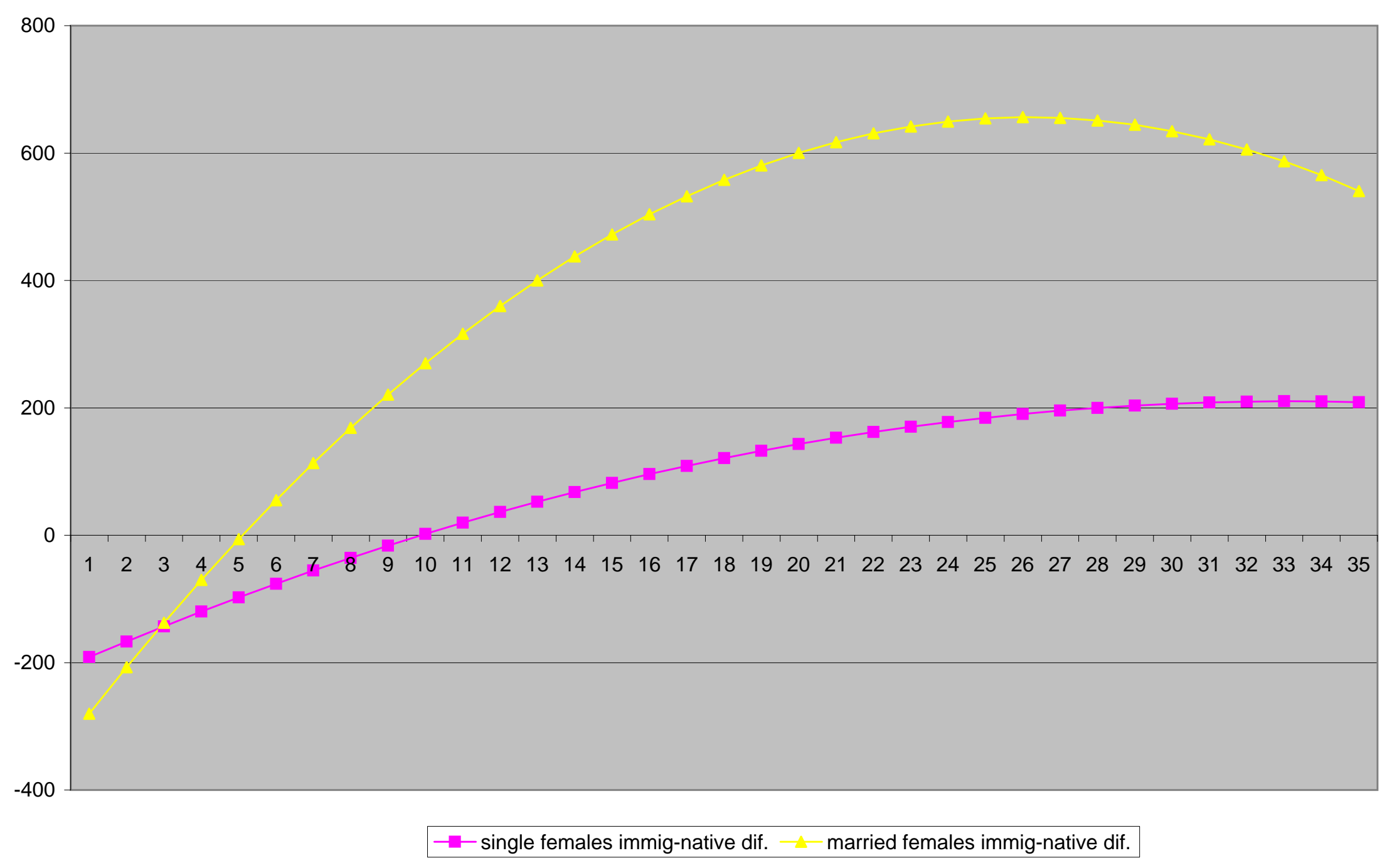


Figure 2b: Work Hours Assimilation Profiles: Married and Single Males, Israel

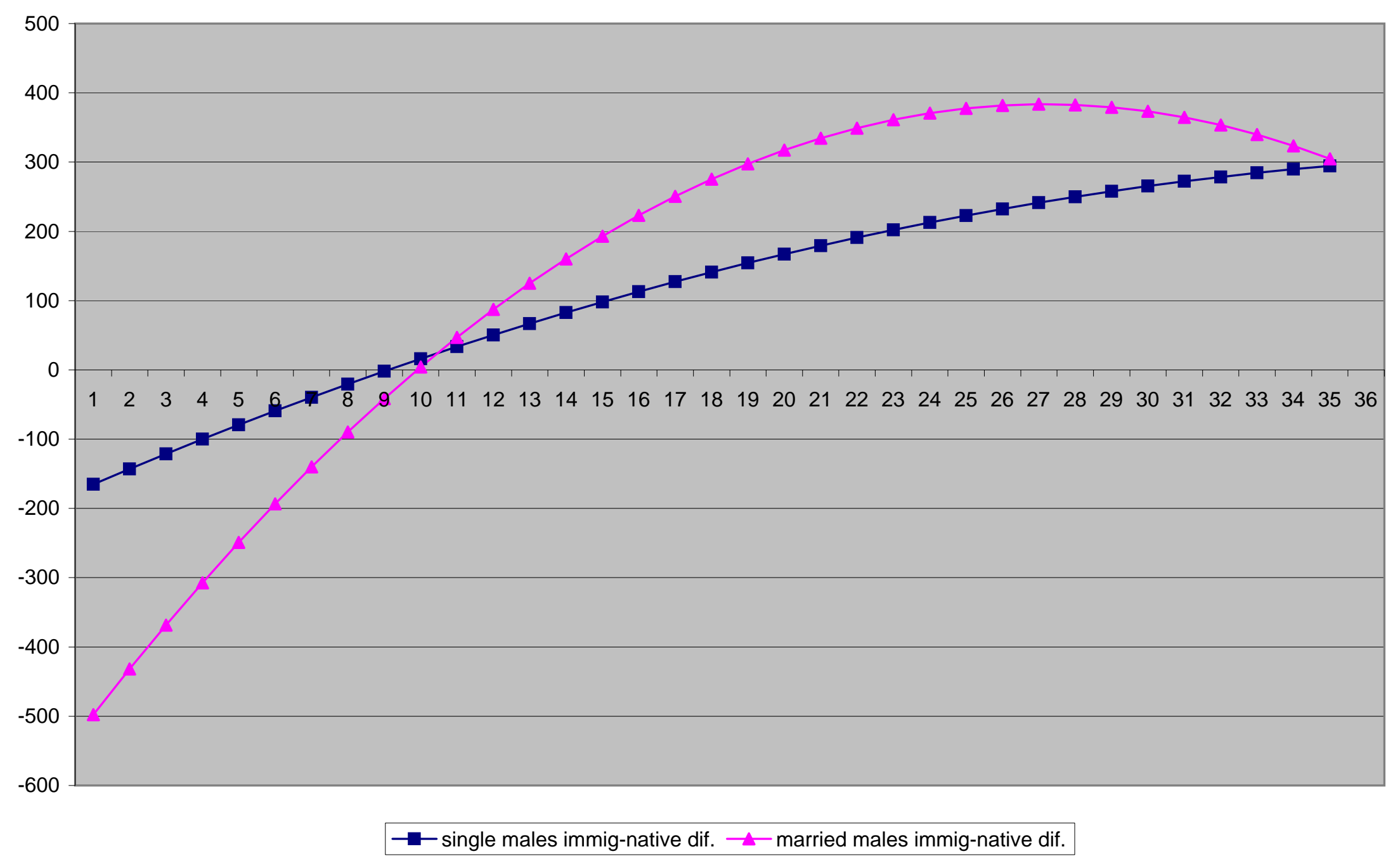


Figure 2c: Work Hours Difference in Differences Profiles, Israel

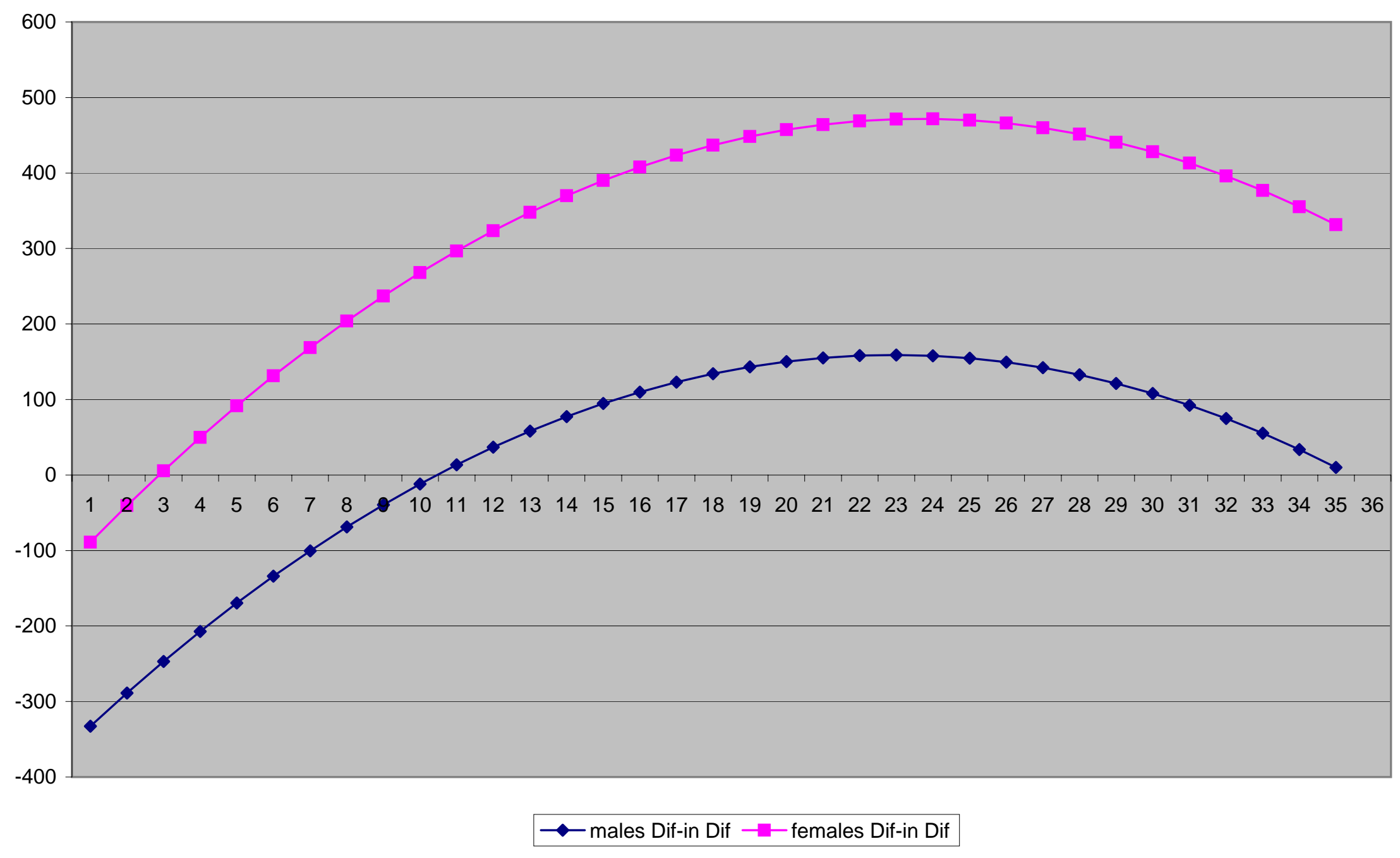


Figure 2d : Wage Assimilation Profiles: Married and Single Females, Israel

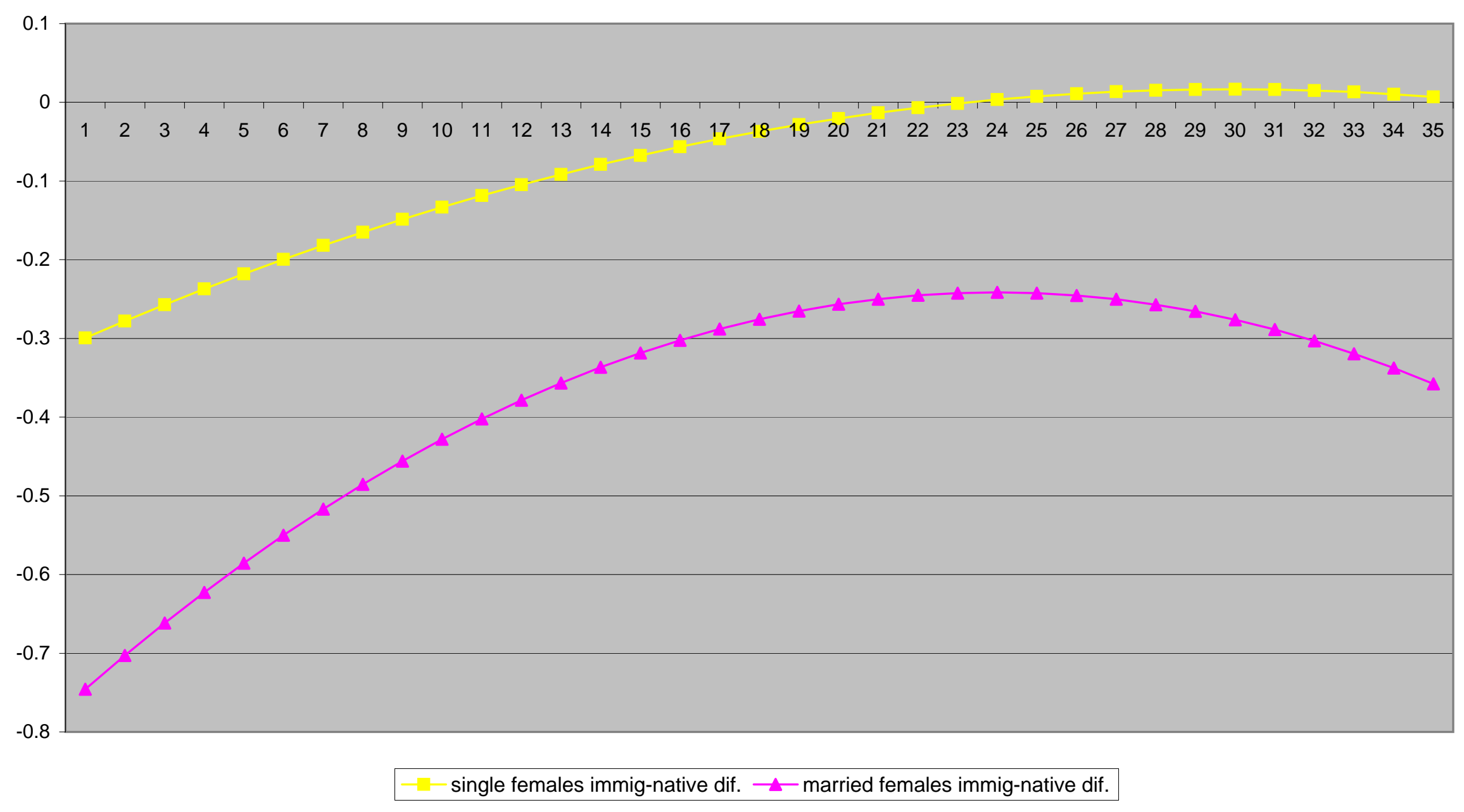


Figure 2e: Wage Assimilation Profiles: Married and Single Males, Israel

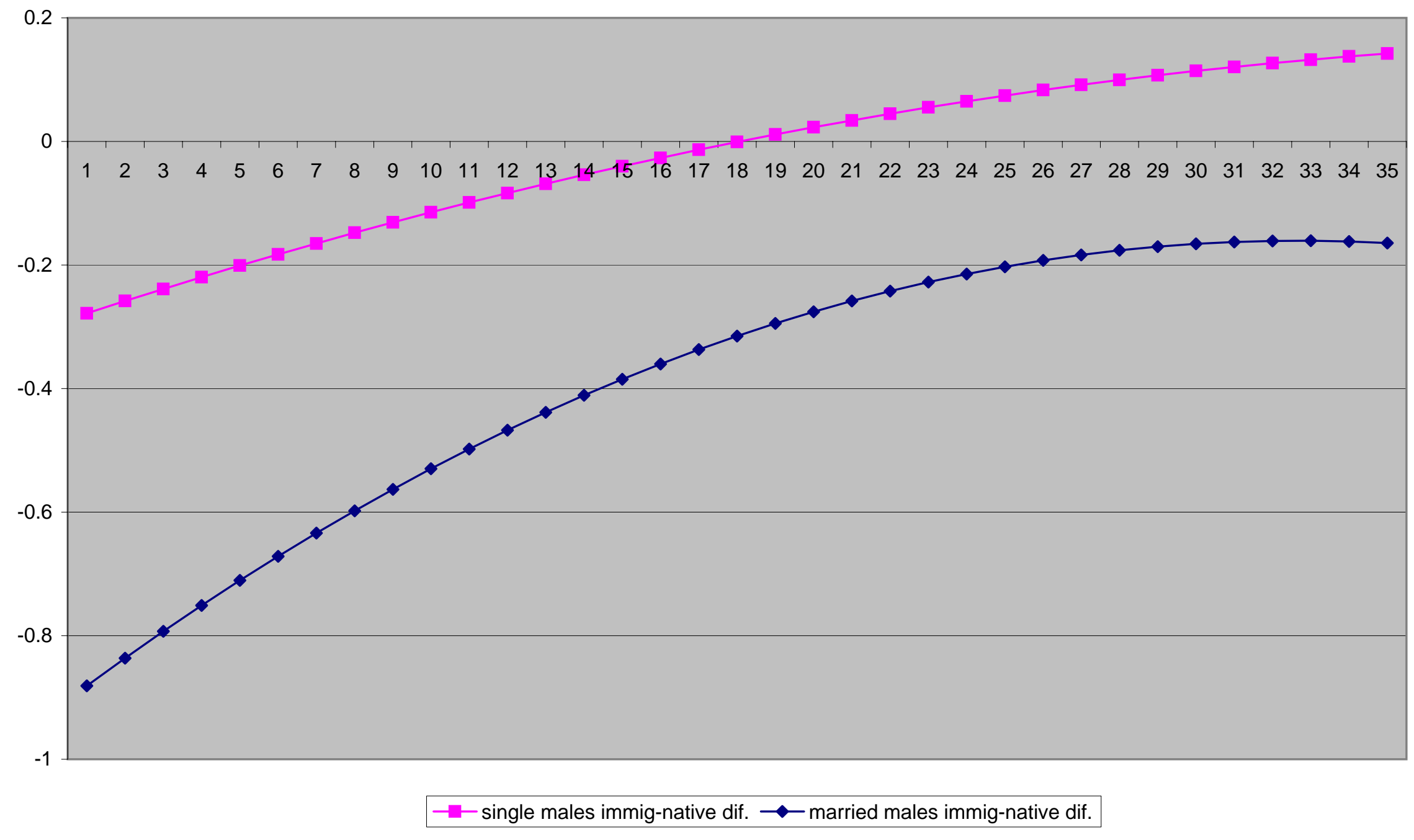


Figure 2f: Wage Difference in Differences Profiles, Israel

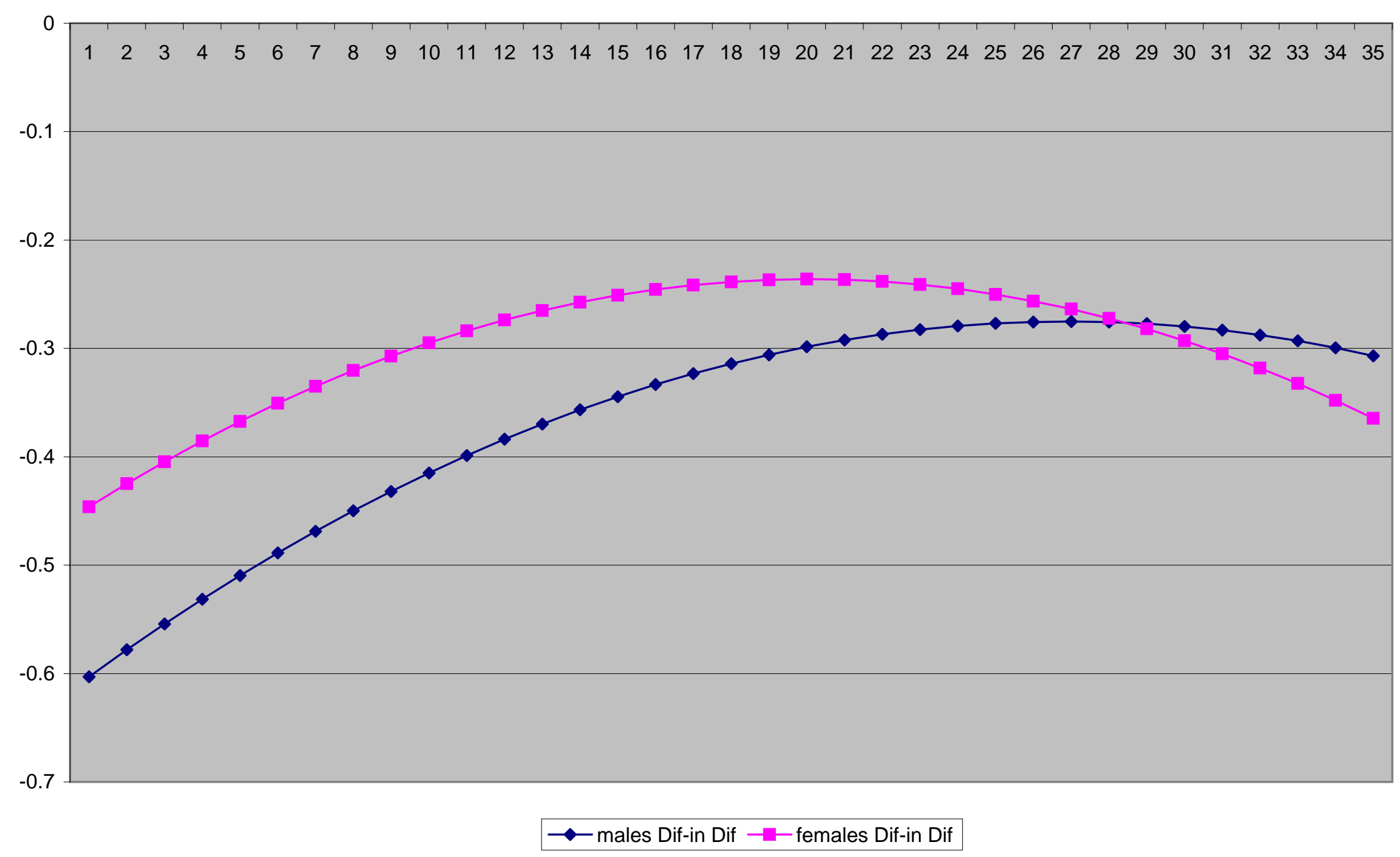

